Journal

of Geography,

Politics and Society

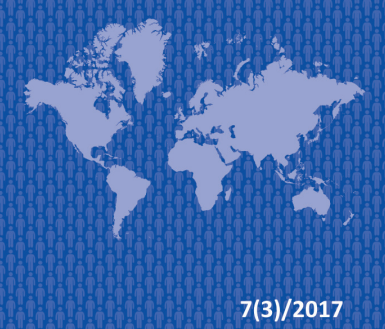

\section{Journal of Geography, Politics and Society}

$2017,7(3), 57-63$

DOI 10.4467/24512249JG.17.028.7184

\title{
TOURIST FLOWS IN TERNOPIL OBLAST CURRENT STATE AND DEVELOPMENT PROSPECTS
}

\author{
Oresta Bordun (1), Liubov Althaim (2) \\ (1) Tourism Department, Faculty of Geography, Ivan Franko National University of Lviv, Doroshenko 41, 79000 Lviv, Ukraine, \\ e-mail: obordun@ukr.net (corresponding author) \\ (2) Geography of Ukraine and Tourism Department, Faculty of Geography, Ternopol National Pedagogical University named after Vladimir Gnatyuk, Kryvonosa 2, \\ 46027 Ternopol, Ukraine, \\ e-mail: altheim@ukr.net
}

\section{Citation}

Bordun O., Althaim L., 2017, Tourist flows in Ternopil oblast: current state and development prospects, Journal of Geography, Politics and Society, 7(3), 57-63.

\begin{abstract}
The features of development of inbound and internal tourism, excursion activity in the Ternopil oblast are exposed in the article. The analysis of tourist activity of touristic agents and tour operators, directions and structure of tourist streams of the Ternopil oblast suggestions of tourist enterprises and level of tourist market of area development is conducted. The special attention is paid to the tourist infrastructure, namely to establishments of placing, feed and leisure. Absence of specialized programs for people of senior age, that elect memorial, biographic or religiously-sentimental tours that are organized, as a rule, without participation of tourist enterprises of the area is marked, and also not enough developed infrastructure, low quality of tourist services, not formed the internal touristic product are mentioned as the components that prevent market from tourist services development.
\end{abstract}

\section{Key words}

Ternopil oblast, tourist industry, inbound tourism, internal tourism, excursion activity, tourist activity, tourist-recreational potential of the area, tourist services, tourist market, excursion routes, tourist infrastructure.

\section{Introduction}

Tourist industry acquires more and more value for development of economy and social sphere in the Ternopil oblast Development of inbound and internal tourism, excursion activity has a tendency for upgrading of life in that area, process of creation additional workplaces, filling of local budget and increase of authority of region both on internal and on international tourist markets.
The Ternopil oblast having an advantageous geopolitical location owns considerable touristrecreational potential favorable climatic terms, plain and mountain landscapes, riches of flora and fauna, developed transport network, plenty of historical sights of culture and architecture.

Tourist industry in the area needs an additional advertising. The special attention should be turned on forming of the positive image of the region in the tourist market of the country and Europe, applying 
PR-technology. Development of infrastructure and creation of favorable terms for business-tourism will give a synergistic effect: workplaces, gap-fillingness of regional budget, stimulation of business activity and bringing in of investments.

\section{Analysis}

Tourist market in Ternopil oblast is represented by tour operators and travel agents who are engaged in creation and sale of tourist products aimed at domestic and foreign areas. According to the Statistics Department of Ternopil oblast tourism activity involved 43 subjects, including 8 tour operators, 33 travel agents and 2 tour operators engaged exclusively in sightseeing activities in 2015 . The vast majority $(88,4 \%)$ of tourism activities was in Ternopil, Kremenets and Zbarazh districts. Income from tourism services (without VAT, excise taxes and similar mandatory payments) amounted to 5884.3 thousand UAH in 2015 (4282 thousand UAH in 2014) (Статистичний..., 2016).

Information on tourist flows in the Ternopil oblast in 2014 and 2015 is given in Figure 1.

Foreign tourism dominates in the structure of tourist flows in Ternopil oblast as domestic tourism products are undeveloped. Domestic offer of travel companies in the oblast is very limited with infrastructure therefore tourist flows are directed to well-known tourist centres such as Pochaiv, Zbarazh, Zarvanytsia, karst caves, Dzhurynskyi waterfall, Terebovlia, Mykulyntsi, Ternopil etc.

Compared to the year 2014, the number of citizens of the oblast, who travelled abroad, increased by $5.9 \%$ and amounted 4970 people most of whom spent there their holidays. The residents of the
Ternopil oblast visited forty-two countries. In 2015 the most popular among the trips abroad were Egypt (1 515 people), Turkey (1 232 people) and Bulgaria (783 people). Typically, tour operators are focused on these tourist countries and this is caused by their pricing. Among the citizens of the oblast, who travelled abroad, 768 people $(15.5 \%)$ were children aged $0-17$ years.

Domestic tourists travelled more often with the purpose of leisure and recreation; statistically their number was 1643 people. 20 museums of the oblast were visited by 618.6 thousand people in 2015 . This figure is much higher than the official number of excursionists and that can be explained by the fact that a majority of tourism enterprises include in a guided tour many museums, memorial estate museum or historical and cultural reserves. In the tourism market there can be observed a revival of tourist flows outside the oblast centre and the residents of other oblast gradually increase interest in local touristic attractions (http://www.te.ukrstat.gov.ua).

To determine the level of development of the tourism market of the oblast it is necessary to analyse statistics on the number of tourists served by the subjects of tourism in the oblast and the total cost of sales of travel packages for the 2014-2015 years and compare them in Table 1.

As you can see the number of sold travel packages over the last year has decreased, but their total value increased by more than 10 thousand USD. Such trends are related to changes in exchange rates and significant inflation in Ukraine.

In 2015 services of tourism enterprises were used by 6.9 thousand people (in $2014-9.1$ thousand people). These were people aged $15-44$ years mostly; rarely firm's clients are children under 14 years old, which go on a trip alone. It was found that the

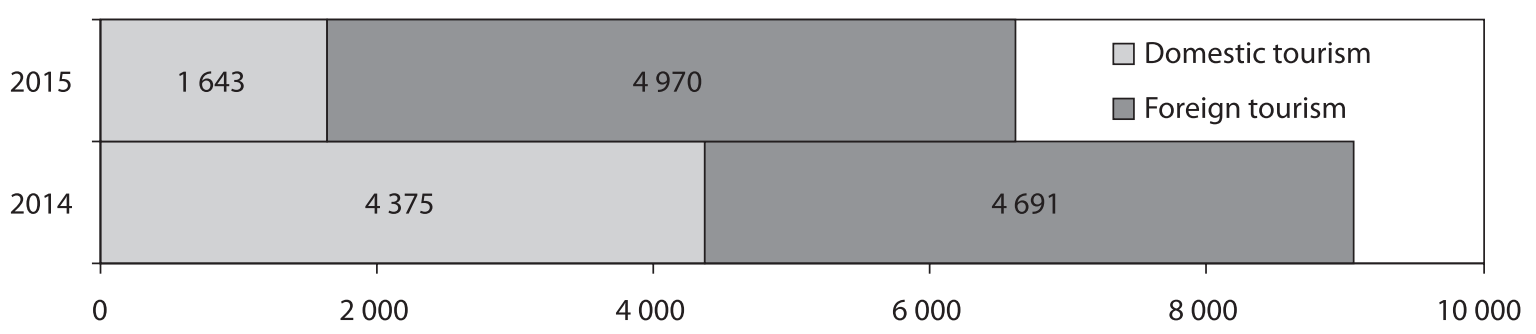

Fig. 1. Number of tourists (person) served the subjects of tourism

Source: http://www.te.ukrstat.gov.ua

Tab. 1. The number and cost of travel packages sold by the subjects of tourism

\begin{tabular}{|c|c|c|}
\hline Year & Number of sold travel packages & The cost of travel packages sold [thous. UAH] \\
\hline 2014 & 3786 & 25151.4 \\
\hline 2015 & 3479 & 37006.6 \\
\hline
\end{tabular}

Source: http://www.te.ukrstat.gov.ua 
proportion of school-age children of all travellers is about $5 \%$ and this is due, primarily, to the lack of specialized children's tours in the local tourism product. Usually children's holiday is health improvement in children's camps. A significant proportion of domestic tourists are pupils, which together with students predominate among the visitors of museums ( $80 \%)$, and therefore among people on an excursions (Програма..., 2016).

The oblast does not have specialized programs for older people, that's why these residents don't use very much the proposals of local tourist companies, although these are the tourists to consume nostalgic tours, the organization which is promising for the Ternopil oblast because of many suitable tourist facilities for these activities. Retirement age visitors, whose share does not exceed $5 \%$, have already been registered in the memorial museums and historical and cultural reserves in general. Among the older visitors greatly dominate foreigners (usually of Ukrainian origin) who choose memorial, biographical or religious and sentimental tours organized usually without the involvement of travel companies of the oblast (Програма..., 2016).

Tourism infrastructure is an important part of the tourism market besides subjects of tourist market. Tourist infrastructure is a set of enterprises and institutions, which are aimed at meeting the needs of people, who are involved in the rehabilitation or recreation, and it includes means of communication, transport and accommodation of tourists providing stable operation conditions. We consider it an integral system consisting of two subsystems: social and production that are interconnected and interdependent regarding service entity (Кузик, 2010, p. 170).

Tourist infrastructure of separate territorial unit is considered to be a combination of companies that provide various services:

- hotels and hostels;

- catering;

- entertainment places etc.

Accommodation facilities. One of the main components of the tourism industry in Ternopil oblast, which determines the real tourism potential, is hotel industry. Hotel enterprises perform one of the most important functions in the service of tourists - accommodation; the quality of accommodation and related services affect the level of tourist service. Hotel industry of Ternopil oblast is represented with different types of temporarily placement for tourists. Although the hotel infrastructure could be much better, you can find both private apartments and estates for rent for tourists, deluxe hotel and some star hotels. At the beginning of 2015 accommodation facilities operated on the territory of Ternopil oblast reached number of 70; their distribution can be seen in Table 2.

However, the actual number of hotel establishments in Ternopil oblast is greater, because many existing hotels are not officially put into operation and are not covered by the statistical reporting. Daily rent services are provided using residential apartments and private hostels in the cities; most of them are unregistered in the state register.

Tab. 2. Accommodation facilities in Ternopil oblast

\begin{tabular}{|c|c|c|}
\hline & 2014 & 2015 \\
\hline Number of accommodation facilities & 70 & 70 \\
\hline Hotels and their analogues & 58 & 58 \\
\hline Hotels & 39 & 39 \\
\hline Motels & 2 & 2 \\
\hline Hostels for visitors & 1 & 1 \\
\hline $\begin{array}{l}\text { Tourist centres, mountain shelters, student summer camps and other places for temporary } \\
\text { accommodation }\end{array}$ & 16 & 16 \\
\hline Special arrangement of vehicles (units) & 12 & 12 \\
\hline Resorts & 3 & 3 \\
\hline Children's sanatoria & 5 & 5 \\
\hline Health centres & 2 & 2 \\
\hline Recreation, leisure other institutions (excluding hostels) & 2 & 2 \\
\hline Health institutions of $1-2$ days stay & - & - \\
\hline Capacity of hotels and their analogues (people) & 2361 & 2361 \\
\hline The number of suits in hotel and their analogues (apartments) & 1158 & 1158 \\
\hline
\end{tabular}

Source: Програма..., 2016. 
The demand for hotel services in many cities and districts of Ternopil oblast often far exceeds supply of the existing accommodation facilities. Acute fluctuations in demand for hotels occur during religious pilgrimages to the pilgrimage centres of the oblast i.e. Zarvanytsia, (Terebovlia District) and Pochaiv (Kremenets District). They also lack the capacity of accommodation establishments. Many local tourist centres (Kryvche, Kasperivtsi, Nyrkiv) have no hotel enterprises at all, while demand for their services here in the summer is quite high.

According to the Central Statistical Office accommodation facilities received 138435 people in Ternopil oblast during 2015. Most people used the services of accommodation in hotels 78103 people, including 7079 foreigners.

However, at present there is insufficient number of budget hotels and hostels. The majority of travellers and active tourists are people with low incomes and, oddly enough, most hotel companies in our oblast are not focused on them. Ternopil oblast lacks quite popular among young people low-cost hostels, network of which is actively developing in other oblasts of Ukraine. Demand for hotel services in parts of the oblast can be seen in Fig. 2.

As we can see the largest number of people used the services of accommodation in Ternopil (38 320) Kremenets (22 739) Borshchiv (3 381) and Zalishchyky (3 532) districts.

58 hotels and similar accommodation facilities provided accommodation service in the oblast in
2015. Among them 14 legal entities and 44 individuals, including 39 hotels, two motels, one hostel for visitors and 16 other places for temporary residence (http://www.te.ukrstat.gov.ua). The most common are hotels $(67.2 \%$ of total), the others are tourist centres, summer camps, seasonal recreation centres, summer houses, which offer a full range of services for reception, accommodation, food and other temporary accommodation facilities.

In 2015, there were 12 specialized accommodation facilities $(0.6 \%$ of all specialized accommodation facilities in Ukraine), including 8 health centres (including 5 for children), 2 health and recreation resorts and two recreation centres. There are health resorts centres: "Zbruch" and "Medobory" (now not operating) in Gusyatin, ophthalmologic centre "Barvinok" in village Manyuky of Zborivsky district, "Veselka" in the village Petrykiv of Ternopil region and "Medobory" in village Konopkivka of Terebovlia district. The largest share of people, which improved health, is $3862 \%$ of the total and they did it in health resort centre "Medobory" (village Konopkivka, Terebovlia district), 15,6\% used "Barvinok" (village Mshanets of Zboriv area) and $13 \%$ - in the sanatorium "Veselka" (village Petrykiv of Ternopil district).

Public catering establishments. The restaurant business of Ternopil oblast includes: restaurants, bars, cafes, canteens, pizzerias and catering services. According to the Central Statistical Office at the beginning of 2015 there were about 1800 institutions of restaurant industry in the Ternopil oblast. Most

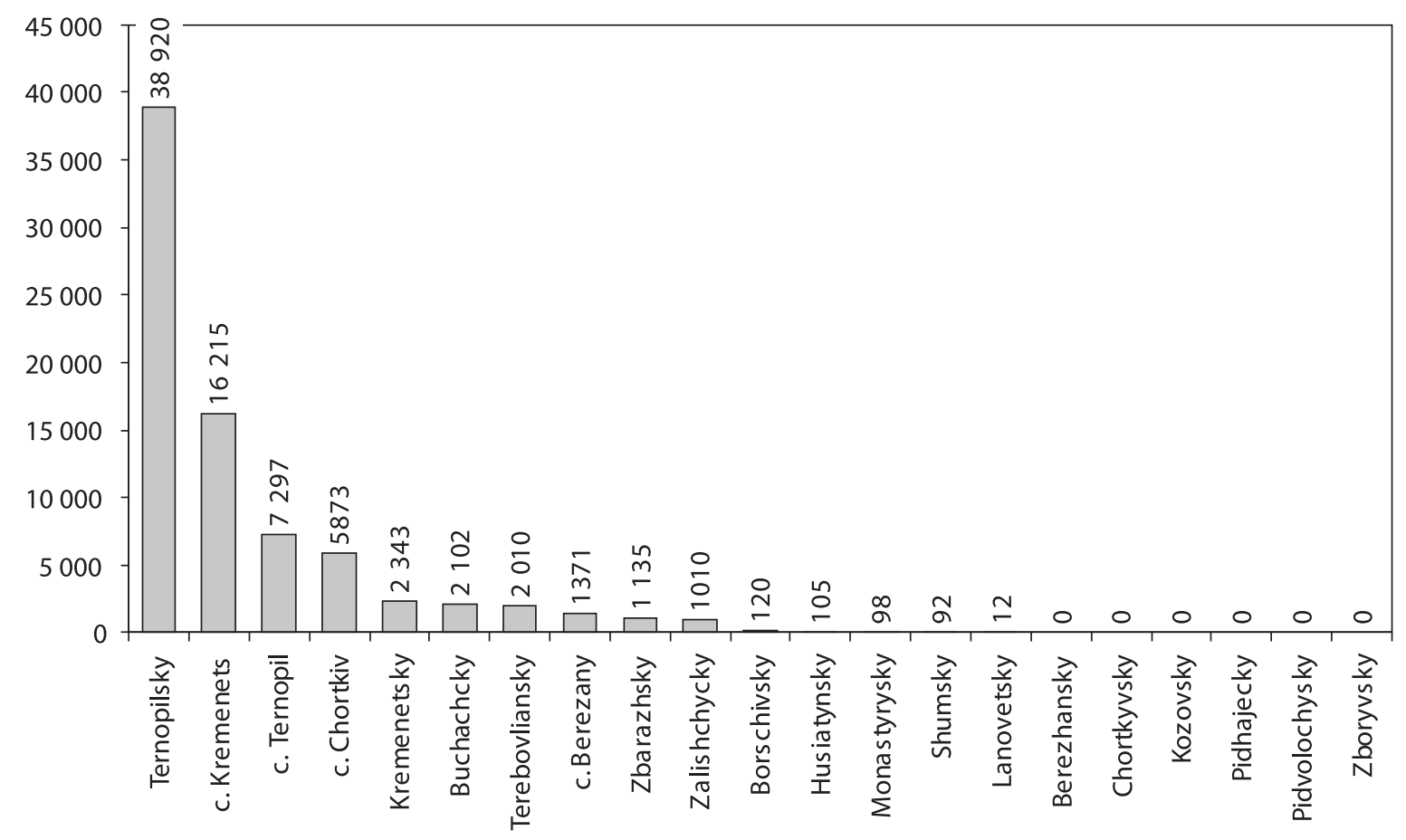

Fig. 2. Number of people received in Ternopil oblast during 2015

Source: Статистичний..., 2016. 
of these facilities are concentrated in Ternopil; they count about 300 objects. A large number of catering companies is also in Buchach, Kremenets and Terebovlia district. Least-developed restaurant business is located in Pidgaetskyi and Monastyrysk districts; there operate about two dozen in each. Most of public catering establishments operate in urban areas, but in recent years, they increase their number and in rural areas. First of all many restaurant establishments are opened in the villages located on the roads of international and national importance. In recent years the segment of specialized and conceptual institutions is actively developing in the market of restaurant services. Such enterprises are also being opened in Ternopil oblast. For example, there are beer pubs in Ternopil and nearby village Mykulyntsi of Terebovlia district. Brewery restaurant "Kovcheg" is the first environmental project in Ternopil. It is partially secured with its own energy sources and designed using technologies applicable for old buildings. The museum restaurant "Stariy mlyn" in Ternopil is an original conceptual restaurant that surprises visitors not only with delicious food, but also with the unique interior.
Modern restaurants and Ukrainian cuisine cafes, besides of Ternopil, have been opened in towns and villages of Zbarazh, Zborivsk, Husyatyn, Kremenets, Terebovlia and Ternopil districts.

The issue of quality of products offered to travellers, individuals and organized tourist groups is very important.

Large facilities of the hotel and restaurant business with a wide range of products and services have regular suppliers of raw materials, but most of catering establishments use products of their own farms and of surrounding villages.

Entertainment facilities. Leisure facilities play an important role in creating tourist product for the young and older generation in the field of tourism market. Tourist route becomes more interesting when it is combined with sightseeing leisure activities. However, most entertainment centres are located in Ternopil, some are in Kremenets, Zalishchyky, Husyatyn and Borshchiv districts. Please note that entertainment is an integral part of any tourism product.

Entertainment facilities in the Ternopil oblast and the services they offer are presented in Table 3.

Tab. 3. Entertainment facilities in Ternopil oblast

\begin{tabular}{|c|c|c|c|}
\hline $\begin{array}{l}\text { Name entertainment } \\
\text { venue }\end{array}$ & Type of institution & Location institution & Services provided by the institution \\
\hline Alligator & $\begin{array}{l}\text { Hotel and recreation } \\
\text { complex }\end{array}$ & Ternopil & $\begin{array}{l}\text { Water park, fitness, aerobics, swim- } \\
\text { ming pool, spa centre }\end{array}$ \\
\hline Podolyany & $\begin{array}{l}\text { Shopping and entertain- } \\
\text { ment centre }\end{array}$ & Ternopil & $\begin{array}{l}\text { Ice centre, bowling alley, cinema, } \\
\text { billiards, etc. }\end{array}$ \\
\hline Somiy Okean & $\begin{array}{l}\text { Shopping and entertain- } \\
\text { ment centre }\end{array}$ & Ternopil & Indoor water park \\
\hline Stara Pidkova & Riding club & Ternopil & Horseback riding \\
\hline Eskimos & $\begin{array}{l}\text { Shopping and entertain- } \\
\text { ment centre }\end{array}$ & Ternopil & Ice centre \\
\hline Maxim & Entertainment complex & Ternopil & Karaoke pub, nightclub, restaurant \\
\hline $\begin{array}{l}\text { Allure, Riverpool, } \\
\text { Bomb }\end{array}$ & Night clubs & Ternopil & Disco, karaoke \\
\hline Symphony & $\begin{array}{l}\text { Hotel \& entertainment } \\
\text { complex }\end{array}$ & $\begin{array}{l}\text { urban type settlement Hu- } \\
\text { siatyn, Husiatyn district }\end{array}$ & Hotel, restaurant \\
\hline Orysya & Tourist \& hotel complex & $\begin{array}{l}\text { village Oryshkivtsi, Husiatyn } \\
\text { district }\end{array}$ & $\begin{array}{l}\text { The hotel sauna, health-care com- } \\
\text { plex"Rapa" }\end{array}$ \\
\hline Zatyshok & Tourist \& hotel complex & Borschiv, Borshchiv district & $\begin{array}{l}\text { Restaurant, hotel, sauna, museum } \\
\text { tavern }\end{array}$ \\
\hline Panorama & $\begin{array}{l}\text { Hotel \& entertainment } \\
\text { complex }\end{array}$ & $\begin{array}{l}\text { Kremenets, Kremenets } \\
\text { district }\end{array}$ & $\begin{array}{l}\text { Hotel, restaurant and entertainment } \\
\text { complex, bicycle rental, bobsleigh } \\
\text { track }\end{array}$ \\
\hline Mishin City & Tourist \& hotel complex & $\begin{array}{l}\text { village Dobrovlyany, Zalish- } \\
\text { chyky district }\end{array}$ & Hotel, restaurant \\
\hline Oasis & Hotel complex & $\begin{array}{l}\text { Zalischyky, Zalishchyky } \\
\text { district }\end{array}$ & Sauna, pool, gym \\
\hline
\end{tabular}


Development of tourism market in the region is prevented with insufficient infrastructure, poor quality of tourist services and undeveloped domestic tourism products. Tourist industry in the oblast is in need of additional advertising. Particular attention should be paid to creating a positive image of the oblast on the tourism market of the state and Europe; PR-technology should be used as well.

The development of infrastructure and creation of favourable conditions for business tourism will have synergistic effect: jobs, pumping the regional budget, business activity stimulation and investment attraction.

\section{Analysis of tourist legislation in Ternopil oblast}

Regulation in the tourism sphere is done by the Verkhovna Rada of Ukraine, the Cabinet of Ministers of Ukraine, central executive authorities, which provide public policy in tourism and resorts, local state administration, local authorities and other bodies within their jurisdiction.

Representative bodies of local self-government village, town, city and regional councils under their authority approve local tourism development program; make local budgets fund the development of local tourism development programs; instruct its executive bodies to fund local programs for tourism development at the expense of the local budget; take measures to encourage business entities engaged in the provision of travel services (Закон..., 1995 p. 181).

Tourism is an important factor of regional development as the principal amount of cultural heritage is concentrated in the small historic centres, which include almost all regional centres. Policies aimed at developing tourism in the regions are an integral part of public policy in the tourism sector and must meet all of the criteria.

Today Ukraine has approved on August 1, 2013 the State Programme of Tourism and Resorts for the period until 2022 (Концепція..., 2013). The Program has its aim to create conditions to increase the flow of tourists a competitive tourism infrastructure developed through rational use of tourism resources, which will increase revenues to budgets of all levels from the proceedings of tourism (Концепція..., 2013).

In order to achieve a new level of tourism and recreation industry Ternopil oblast has created a competitive tourist product, which is called "The program of tourism development in the Ternopil oblast in 2016-2020 years" (Програма..., 2016).
It notes that Ternopil oblast is a recognized tourist region positioned in Ukraine and abroad thanks to well-known brands such as "Dniester Canyon", "Castles of Ternopil", "Caves of Ternopil oblast", "Borshchiv embroidery", "Buchach and Pinsel", "Chervonohorod natural landmark" "Picturesque Berezhany", "Medobory, Tovtry invite". It also defines priority directions of tourism development in the oblast based on existing tourism resources (Програма......, 2016).

The program aims at:

- development and implementation at the national and international markets competitive tourism product able to meet the travel needs of area residents and their guests;

- creation and development of logistics and modern tourism infrastructure, of favourable conditions for investment, of efficient use of natural, historical and cultural tourist and recreational potential and ensuring conditions for full functioning of tourism;

- improvement of the quality and range of tourist services, expansion of the network of tourist and excursion routes, the implementation of a system of advertisement and information activities, support for inbound and domestic tourism, improvement of the staffing of the tourism industry in the region.

This program is intended to be a conceptual basis for the development of tourism in the oblast as a highly profitable sector of the economy. Taking into account the magnitude of the task, the program needs a strong funding from the state, regional, district and city budgets as well as extra-budgetary funds. The program is designed in accordance with current law and takes into account the basic requirements of laws of Ukraine "On Tourism" (Закон України «Про туризм» від 15.09.1995), "On foreign economic activity" (Закон України «Про зовнішньоекономічну діяльність» від 16.04.1991), “On local government in Ukraine" (Закон України «Про місцеве самоврядування в Україні» від 21.05.1997), "On innovation activity" (Закон України «Про інноваційну діяльність» від 04.07.2002), “On local state administrations" (3aкон України «Про місцеві державні адміністрації» Закон від 09.04.1999) and other legal acts governing tourism and recreation industry in Ukraine.

While program development there were defined following strategic objectives:

Strategic goal A. Formation of regional tourism product of high-quality.

Strategic goal B. Formation of an effective system of promoting tourism brand and integrated regional tourism product on the Ukrainian and international markets. 
Strategic goal C. Formation of a favourable environment for business and investment processes in the tourism and recreation industry in the region.

\section{Conclusions}

Most of tourist enterprises of the Ternopil oblast are orientated on outbound tourism and offer foreign tours. However the domestic tourist product becomes more popular lately. Touristic agencies develop excursion routes in territory of area, but very often tourists are beware of their services due to the shortage of information and advertisement. Advancement of tourist product of the Ternopil Region both on the internal and international markets of tourist services is impossible without the proper advertisement providing. It is a very effective constituent of the system of marketing communications and it needs considerable charges. Introduction of PR marketing communications in a tourist sphere is necessary pre-condition of it's development. Not less important are objectivity of information, lightness of access and operationability of it receipt, plenitude, evidentness, possibility of interactive registration of orders and payment of services. An advertisement must answer the requirements of the tourist business, and also individual necessities of tourists and sightseers.

\section{References}

Головне управління статистики у Тернопільській області, Тернопіль, http://www.te.ukrstat.gov.ua, [10.03.2017]

Закон України «Про зовнішньоекономічну діяльність» від 16.04.1991 № 959-XII, 1991, чинний, поточна редакція від 03.01.2017, http://zakon2.rada.gov.ua/laws/show/959-12 [10.03.2017]

Закон України «Про інноваційну діяльність» від 04.07.2002 № 40-IV, 2002, чинний, поточна редакція від 05.12.2012, http://zakon2.rada.gov.ua/laws/show/40-15 [10.03.2017]

Закон України «Про місчеве самоврядування в Україні» від 21.05.1997 № 280/97-ВР, 1997, чинний, поточна редакція від 01.01.2017, http://zakon2.rada.gov.ua/laws/ show/280/97 [10.03.2017]

Закон України «Про місцеві державні адміністрації» Закон від 09.04.1999 № 586-XIV, 1999, чинний, поточна редакція від 01.05.2016, http://zakon3.rada.gov.ua/laws/ show/586-14 [10.03.2017]

Закон України «Про туризм» від 15.09.1995 № 324/95-ВР, 1995, чинний, поточна редакція від 11.02.2015, http:// zakon2.rada.gov.ua/laws/show/324/95 [10.03.2017]

Концепція Державної цільової програми розвитку туризму та курортів на період до 2022 року від 1 серпня 2013 р. № 638-p, 2013, http://zakon3.rada.gov.ua [10.03.2017]
Кузик С., 2010, Теоретичні проблеми туризму: суспільногеографічний підхід, Видавничий центр ЛНУ ім. Івана Франка, Львів.

Програма розвитку туризму в Тернопільській області на 2016-2020 роки, 2016, Тернопільська обласна державна адміністрація, Тернопіль, http://www.oda.te.gov.ua [10.03.2017]

Статистичний бюлетень «Туристична діяльність у Тернопільській області», 2016, Головне управління статистики у Тернопільській області, Тернопіль. 